\title{
DÜBLIN
}

Technological University Dublin

ARROW@TU Dublin

\section{Effect of Calcium Lactate and Heat-Shock on Texture in Fresh-Cut Lettuce During Storage}

\author{
Ana Belen Martin-Diana \\ Technological University Dublin, anabelen.martindiana@tudublin.ie \\ Daniel Rico \\ Technological University Dublin, daniel.rico@tudublin.ie \\ Jesus Maria Frias \\ Technological University Dublin, Jesus.Frias@tudublin.ie
}

See next page for additional authors

Follow this and additional works at: https://arrow.tudublin.ie/schfsehart

Part of the Food Microbiology Commons

\section{Recommended Citation}

Martin-Diana, A., Rico, D., Frias, J. Henehan, G., Mulcahy, J., Barat, J., Barry-Ryan, C. (2006). Effect of calcium lactate and heat-shock on texture in fresh-cut lettuce during storage. Journal of Food

Engineering, 77(4), pp. 1069-1077. doi:10.1016/j.jfoodeng.2005.08.037

This Article is brought to you for free and open access by the School of Food Science and Environmental Health at ARROW@TU Dublin. It has been accepted for inclusion in Articles by an authorized administrator of ARROW@TU Dublin. For more information, please contact arrow.admin@tudublin.ie, aisling.coyne@tudublin.ie, gerard.connolly@tudublin.ie.

Funder: Technological Sector Research Grant (2002-2006). 


\section{Authors}

Ana Belen Martin-Diana, Daniel Rico, Jesus Maria Frias, Gary Henehan, Jemina Mulcahy, J. Barat, and Catherine Barry-Ryan 


\title{
Effect of calcium lactate and heat-shock on texture in fresh-cut lettuce during storage
}

\author{
Journal of Food Engineering 77 (2006) 1069-1077
}

\author{
A.B. Martın-Dianaa, D. Ricoa, J. Frıasa, G.T.M. Henehana, J. Mulcahya, \\ J.M. Baratb, \& Catherine Barry-Ryan a \\ School of Food Science and Environmental Health, Dublin Institute of Technology (DIT), Cathal Brugha Street, \\ Dublin 1, Ireland \\ Institute of Food Engineering for Development, Department of Food Technology, Universidad Politecnica, \\ Camino de Vera s/n, 46022 Valencia, Spain
}

\begin{abstract}
Textural and microstructural changes in fresh-cut lettuce were analysed over 12 days storage. The vegetable was treated with 120 ppm chlorine and with $15 \mathrm{~g} / \mathrm{L}$ calcium lactate at room temperature $\left(\$ 18-20^{\circ} \mathrm{C}\right.$ ) and at $50{ }^{\circ} \mathrm{C}$ (heat-shock). Texturometer analysis showed that samples washed with calcium lactate had significantly $(p>0.05)$ higher crispness values than samples washed with chlorine. However the use of $50{ }^{\circ} \mathrm{C}$ treatment (heat-shock) gave better textural properties at the end of storage and significantly retarded the softening process, being in agreement with the sensorial results. Cryo-SEM micrographs showed a loss of turgor (shrinkage) of the tissue cells in the samples washed with chlorine, effect not so evident in calcium lactate treated samples. The use of heat-shock in combination with calcium lactate reduced this phenomenon better than the other two treatments. Pectin methyl esterase (PME), enzyme related to textural changes, showed higher activity in samples treated with calcium lactate at $50^{\circ} \mathrm{C}$. The combination of calcium lactate and $50^{\circ} \mathrm{C}$ washing temperature maintained objective and sensorial textural properties of fresh-cut lettuce better than the calcium lactate or chlorine washing treatments at room temperature.
\end{abstract}

Keywords: Fresh-cut lettuce; Calcium lactate; Heat-shock; Texture; Cryo-SEM

\section{Introduction}

Consumers attitudes have changed during recent decades: sales of ready-to-use fresh vegetables have grown rapidly as result of consumers demand. The main food trends are towards product quality, convenience and fresh-like character (Ohlsson, 1994). The association between fresh vegetables consumption and the reduction in the risk of certain chronic diseases (Ruowei, Serdula, Bland, Mokdad Bowman, \& Nelson, 2000; Subar et al., 1995) have contributed to these trends.

Fresh-cut processed vegetables are defined as those subjected to some processing techniques of lesser magnitude than canning or freezing, but which nevertheless added value to the product before distribution and consumption (King \& Bolin, 1989). The marketing of fresh-cut vegetables, especially leaf vegetables, is limited by a short shelflife and rapid deterioration of their components due to tissue damage as a result of washing, cutting etc. (Watada \& Qui, 1999).

Iceberg lettuce is a species of lettuce more popular than others such as butterhead, lollo rosso, and romaine. This is probably due to its crispness and attractive yellow-green colour. However, after the cutting, the product undergoes different undesirable biochemical reactions associated with wounding (Brecht, 1995; Watada \& Qui, 1999).

Textural changes are among the main causes of quality loss for these products. Texture is seldom maintained for more than ten days, even under optimal storage conditions. 
Minimally processed vegetables that maintain firm, crunchy textures are highly desirable because consumers associate these textures with freshness and wholesomeness (Bourne, 2002; Fillion \& Kilcast, 2000, 2002; Szczesniak, 1998). Indeed, the appearance of a soft or limp product may give rise to consumer rejection prior to consumption.

Different preservation methods are used in order to improve the textural properties during storage such as vacuum impregnation (Grass, Vidal, Betoret, Chiralt, \& Fito, 2003), preheating (Vu et al., 2004), electric pulses (Giner et al., 2000), irradiation (Han, Gomes-Feitosa, Castell-Perez, Moreira, \& Silva, 2004), amongst others.

The consumption of functional foods has increased greatly during the last decade (Mazza, 1998). For this reason, finding preservation methods that extend shelf-life (reduce browning, maintain texture and control microbial population) and at the same time enhance the nutritional value of the product is one of the priorities of the food industry.

Calcium is associated with maintaining the cell wall structure of vegetables by interacting with pectin to form calcium pectate. Calcium is reported to maintain firmness by cross-linking with both cell wall and middle lamella pectin (Grant, Morris, Rees, Smith, \& Thom, 1973). Thus, fruit and vegetables treated with calcium are generally firmer than controls during storage (Camire, Ismail, Work, Bushway, \& Halteman, 1994; Lester \& Grusak, 1999; Luna-Guzman, Cantwell, \& Barrett, 1999; Suutarinen, Anakainen, \& Autio, 1999). Calcium lactate 5-30 g/L has been used as a firming agent for fruits such as cantaloupes, strawberry and carrots among others (Main, Morris, \& Wehunt, 1986; Martin-Diana et al., 2005-a; Morris, Sistrunk, Sims, Main, \& Wehunt, 1985). It has been reported that calcium lactate is a good alternative to calcium chloride because avoids the bitterness or off-flavours associated with the chloride salt (Luna-Guzman \& Barrett, 2000). Moreover, the calcium content of the diet is critical in most stages of life (Grass et al., 2003).

Heat-shock treatments, alone or combined with other agents (calcium, chlorine), have also been used to prevent browning reactions and maintain texture in various vegetables and fruits (Hisaminato, Murata, \& Homma, 2001; Loaiza-Velarde, Tomas-Barberan, \& Salveit, 1997). Heat treatment results in tissue firming in potatoes (Bartolome \& Hoff, 1972) and tomatoes (Floros, Ekanayake, Abide, \& Nelson, 1992). Firming effects obtained from heat treatments alone or combined with calcium treatments have been attributed to the action of heat-activated pectin methyl esterase (PME) and/or to increased calcium diffusion into tissues at higher temperatures (Bartolome \& Hoff, 1972; Garcia, Herrera, \& Morilla, 1996).

The texture evaluation of the lettuce is relatively difficult due to the heterogeneity of the product. Photosynthetic and vascular tissues present vastly different textural properties (Toole, Parker, Smith, \& Waldron, 2000).

Another problem is the difficulty of how to evaluate the crispness characteristic using the readings obtained from the texture tests (Harker, Stec, Hallett, \& Bennett, 1997; Vickers, 1988). Previous experience in this laboratory showed the use of a penetrometer cell (puncture cell) in fresh-cut Iceberg lettuce (Martin-Diana et al., 2005-a) not sensitive enough to find differences between treatments. Moreover, a penetrometer test might not be appropriate to test a textural property which is based in breaking and chewing characteristic responses. Furthermore, the small surface area exposed to analysis combined with the high tissue variability may contribute to poor repeatability. Later studies showed higher sensitivity and repeatability using the Kramer cell to evaluate texture in lettuce, in agreement to other authors (Baur, Klaiber, Wei, Hammes, \& Carle, 2005; Han et al., 2004). In these studies the texture is evaluated using the maximum load to break the sample. However, our experience makes us to consider than this does not reflect the crispiness attribute, which is the first textural characteristic related to freshness for lettuce. Crispness can be more related to the type of breaking and sound produced than the maximum load needed. Also, crispness has been proposed to be an auditory sensation (Vickers, 1988).

Studies on lettuce have generally been limited to sensory attributes, general appearance, wilting, decay and physiological disorders conducted mostly during investigations on the packaging and storage conditions (Alsadon, 1993;

'Artes \& Martinez, 1996; Heimdal, Kuhn, Poll, \& Larsen," 1995; Toole et al., 2000). For this reason in this study objective (Instron texturometer, Cryo-SEM, PME activity) and subjective (sensorial analysis) measurements were carried out to analyse the effect of different washing treatments on textural changes during storage of fresh-cut lettuce.

\section{Materials and methods}

\subsection{Processing and experimental set up}

Iceberg lettuce (Lactuca sativa sp.) was purchased in a local supermarket and stored at $4^{\circ} \mathrm{C}$ before processing. Three washing treatments were conducted in parallel, prepared from the same batch of product. The two outer leaves were removed by hand and the core was excised with a stainless steel knife. The other parts of the lettuce were cut in half and each half was further cut into four pieces. The temperature in the processing plant was $\$ 18-20^{\circ} \mathrm{C}$ (room temperature).

Washing treatments of lettuce were performed by immersion of the fresh-cut lettuce in each treatment solution. The samples were sanitised with chlorinated water (120 ppm) and calcium lactate (15 g/L) at room temperature $\left(\$ 18-20^{\circ} \mathrm{C}\right)$ and $50^{\circ} \mathrm{C}$. Chlorinated water was prepared by adding sodium hypochlorite solution (P120 g/L available chlorine) to distilled water to obtain $120 \mathrm{mg} / \mathrm{L}$ free chlorine ( $\mathrm{pH} \$ 8)$. Calcium lactate (Sigma, USA) was diluted to $15 \mathrm{~g} / \mathrm{L}(\mathrm{pH}=6.5)$. For all treatments the solutions were prepared using distilled water stored at 
room temperature $\left(\$ 18-20^{\circ} \mathrm{C}\right)$. Each treatment was carried out in different baskets ( $\$ 200 \mathrm{~g}$ vegetable product $/ \mathrm{L}$ ) and immersed in the corresponding washing solution for $1 \mathrm{~min}$ with agitation and subsequently dried for $5 \mathrm{~min}$ using an automatic salad spinner.

Free chlorine concentration in the washing water was determined using a DREI/2000 spectrometer with appropriate AccuVacò pillows (Hach Company, Loveland, Colorado, USA), using the DPD method.

Processed vegetables were pooled, mixed and subsequently packaged in bags $(200 \cdot 320 \mathrm{~mm})$ of $35 \mathrm{Im}$ oriented polypropylene (OPP) (Amcor Flexibles Europe-Brighouse, United Kingdom). Each package contained $\$ 100 \mathrm{~g}$ of product. The packages were chilled in a blast freezer at $0{ }^{\circ} \mathrm{C}$ for 2 min before heat-sealing under atmospheric conditions and stored at $4{ }^{\circ} \mathrm{C}$ for 12 days.

Three independent batches were carried out. Each batch consisted in $\$ 12 \mathrm{~kg}$ (\$34 heads of lettuce of $\$ 350 \mathrm{~g}$ ), and 32 bags per treatment ( $\$ 100 \mathrm{~g}$ per bag) were packaged. The total number of bag per batch was 96 .

\subsection{Cryo scanning electron microscopy (Cryo-SEM)}

Cryo-SEM was used to observe the effects of wounding stress on processed samples. Rectangular pieces $4 \cdot 5 \mathrm{~mm}$ were cut from the wounded area to the centre of the samples.

The samples were frozen by immersion in Slush Nitrogen $\left(\mathrm{A} 210^{\circ} \mathrm{C}\right)$. After that, the samples were fractured, etched (at À94. $5^{\circ} \mathrm{C}, 10$ Às Torr vacuum, for $15 \mathrm{~min}$ ), gold coated and viewed in the cold-stage scanning electron microscope (JEOL JSM-5410). Using this technique, the fractured surface of the frozen sample was viewed directly while being maintained at À $150^{\circ} \mathrm{C}$ or lower (Bomben \& King, 1982). Two samples per treatment and day were used and \$10 micrographs per sample were obtained.

\subsection{Instron analysis}

Texture properties of lettuce were assessed using an Instron texture analyser (Instron 4302 Universal Testing Machine, Canton MA, USA). A $500 \mathrm{~N}$ load cell was attached. For lettuce a Kramer shear cell with an 8 blade probe attached to the instrument was used. The speed setting for the experiment was $100(\mathrm{~mm} / \mathrm{min})$ and load was reported $(\mathrm{KN} / \mathrm{g})$. Segregation of tissue and orientation were done for the analysis. All tests were performed with photosynthetic tissue. Rectangular pieces $(3 \cdot 6.5 \mathrm{~cm})$ were cut and put in the Kramer cell. Maximum load (load at rupture point)/sample weight and the coefficient [(max load-min load/max load)/sample weight], which was defined like crispiness coefficient (CC) were analysed.

Previous results showed that it was necessary to obtain a minimum of 25 samples, to approximate results to a log normal curve. Data were analysed with the Instron series IX software for Windows.

\subsection{Dry matter}

A piece of lettuce was heated at $100{ }^{\circ} \mathrm{C}$ for $2 \mathrm{~h}$ in a Universal Oven (Memmert, Schwabach, Germany) and weighted before and after the heating. Four replicates per treatment and day were carried out. The dry matter was calculated as percentage (\%) of dry matter weight related to fresh product weight.

\subsection{Sensory texture analysis}

Sensory analysis was performed for lettuce over 12 days of storage time by a panel with an age range of 25-40 years. Texture was scored on a hedonic scale of $0-5$. The texture was evaluated by the fracture of different pieces of lettuce with the fingers. The 12-member sensory panel was selected from among the members of the department and the evaluation was carried out in the sensory evaluation laboratory. Data analysis was carried out with Compusenseò Five software (Release 4.4, Ontario, Canada).

\subsection{Pectin methyl esterase activity (PME) E.C.3.1.1.11}

PME activity was measured using the method described by Kimball (1991). Briefly, $10 \mathrm{~g}$ of tissue was diluted in an extraction solution ( $0.2 \mathrm{M}$ sodium phosphate buffer, $\mathrm{pH}$ 7.5 containing $1 \mathrm{M}$ sodium chloride and $10 \mathrm{mM}$ dithiothreitol) and homogenised at $4{ }^{\circ} \mathrm{C}$ for $2 \mathrm{~min}$ at $5500 \mathrm{rpm}$. The macerate was incubated at $4{ }^{\circ} \mathrm{C}$ for 30 min with agitation and centrifuged at $12,500 \mathrm{~g}$ for $30 \mathrm{~min}$ at $4{ }^{\circ} \mathrm{C}$. One milliliter of this extract was mixed with $40 \mathrm{~mL}$ of substrate solution ( $0.1 \%$ pectin). The solution was adjusted to $\mathrm{pH} 7.0$ with $1.0 \mathrm{M} \mathrm{NaOH}$, and the $\mathrm{pH}$ of the solution was re-adjusted to $\mathrm{pH} 7.5$ with $0.05 \mathrm{M} \mathrm{NaOH}$. After the $\mathrm{pH}$ reached 7.5; $0.2 \mathrm{~mL}$ of $0.05 \mathrm{~N} \mathrm{NaOH}$ was added. The time required to return to $\mathrm{pH} 7.5$ was recorded. Activity was quantified as carboxyl groups formed by the hydrolysis of methyl esters of pectin and was measured tritrimetrically using a $\mathrm{pH}$ electrode to monitor the production of $\mathrm{H}_{+}$. PME activity units were calculated using the following formula (Kimball, 1991), the enzymatic activity can be described by

$$
\begin{aligned}
\text { PME activity }= & (0.05 \mathrm{~N} \mathrm{NaOH}) *(\mathrm{X} \mathrm{mL} \text { extracted }) \\
& *(0.2 \mathrm{~mL} \mathrm{NaOH}) * 10^{6} /(1 \mathrm{~mL} \text { sample }) \\
& *(10 \mathrm{~g} \mathrm{sample}) *(\text { Time in min }) .
\end{aligned}
$$

Two macerates per treatment and day were prepared. Triplicates of the enzymatic activity were completed.

\subsection{Statistical analysis}

Differences among the treatment and storage samples were tested by multi analysis of variance (MANOVA). Differences are reported as significant to 95\% LSD interval. Statgraphics software (version 2.1; Statistical Graphics Co., Rockville, USA) was used to analyse the data. Three independent trials or batches were carried out. 


\section{Results and discussion}

Preliminary studies in this laboratory have shown the effectiveness of using calcium lactate washing treatments to extend the shelf-life of fresh-cut vegetables (MartinDiana et al., 2005-a). Further investigations showed that the use of heat-shock $\left(50^{\circ} \mathrm{C}\right)$ combined with the use of calcium lactate $(15 \mathrm{~g} / \mathrm{L})$ was the most effective treatment for the control of enzymes which play an important role in the loss (polyphenol oxidase and peroxidase) and maintenance (pectin methyl esterase) of quality (MartinDiana et al., 2005-b, 2005-c).

\subsection{Cryo scanning electron microscopy (Cryo-SEM)}

Scanning electron microscopy of lettuce samples was carried out over 12 days storage at $4{ }^{\circ} \mathrm{C}$ for samples treated with chlorine and calcium lactate at room temperature (18$20^{\circ} \mathrm{C}$ ) and calcium lactate at $50{ }^{\circ} \mathrm{C}$ (heat-shock) (Figs. 1 and 2). Photosynthetic tissues from each lettuce sample were analysed in order to observe microscopic structural changes. The observation of the sample, in all the cases, was performed after fracturing the tissue perpendicular to vascular axes.

Cryo-SEM images showed the internal cellular features as a dispersed network that in agreement with other authors (Roy, Watada, Conway, Erbe, \& Wergin, 1994) might correspond to membrane and cell wall fragments which are dispersed after the sublimation process used for sample preparation.

In Fig. 1 the effect of the washing treatment on tissue morphology after 1 day of storage can be observed. For all treatments the cell walls appeared well-defined and there was no visible gap between cell wall and membrane. The development of a gap between cell wall and membrane is often referred to an incipient plasmolysis and has been described in other vegetables and fruits (Rojas, Gerschenson, \& Marangoni, 2001). However after the treatment the fresh-cut lettuce treated with chlorine showed a higher loss of turgor than samples treated with calcium lactate at room temperature and at $50{ }^{\circ} \mathrm{C}$. This loss of turgor could be related to a higher loss of water in lettuce treated with chlorine, due to the higher stress produced by this treatment during processing (Roy et al., 1994). These differences in turgor could be explained by changes in osmotic pressure (Rojas et al., 2001), which can affect to the cell shape after wounding. Thus, we observed a better maintenance of turgor in fresh-cut lettuce treated with calcium lactate (Fig. 1). This may be associated with the effect of calcium on the maintenance of cell wall structure by its interaction with pectic acid in the cell wall to form calcium pectate.

Samples treated with chlorine showed a reduction in size cell compared with other treatments (Fig. 2). This may be associated with the loss of turgor after the treatment. The crispness textural characteristic has been associated with cell turgor (Bourne, 1976). Rojas et al. (2001) have suggested that since the plasmalemma has little mechanical
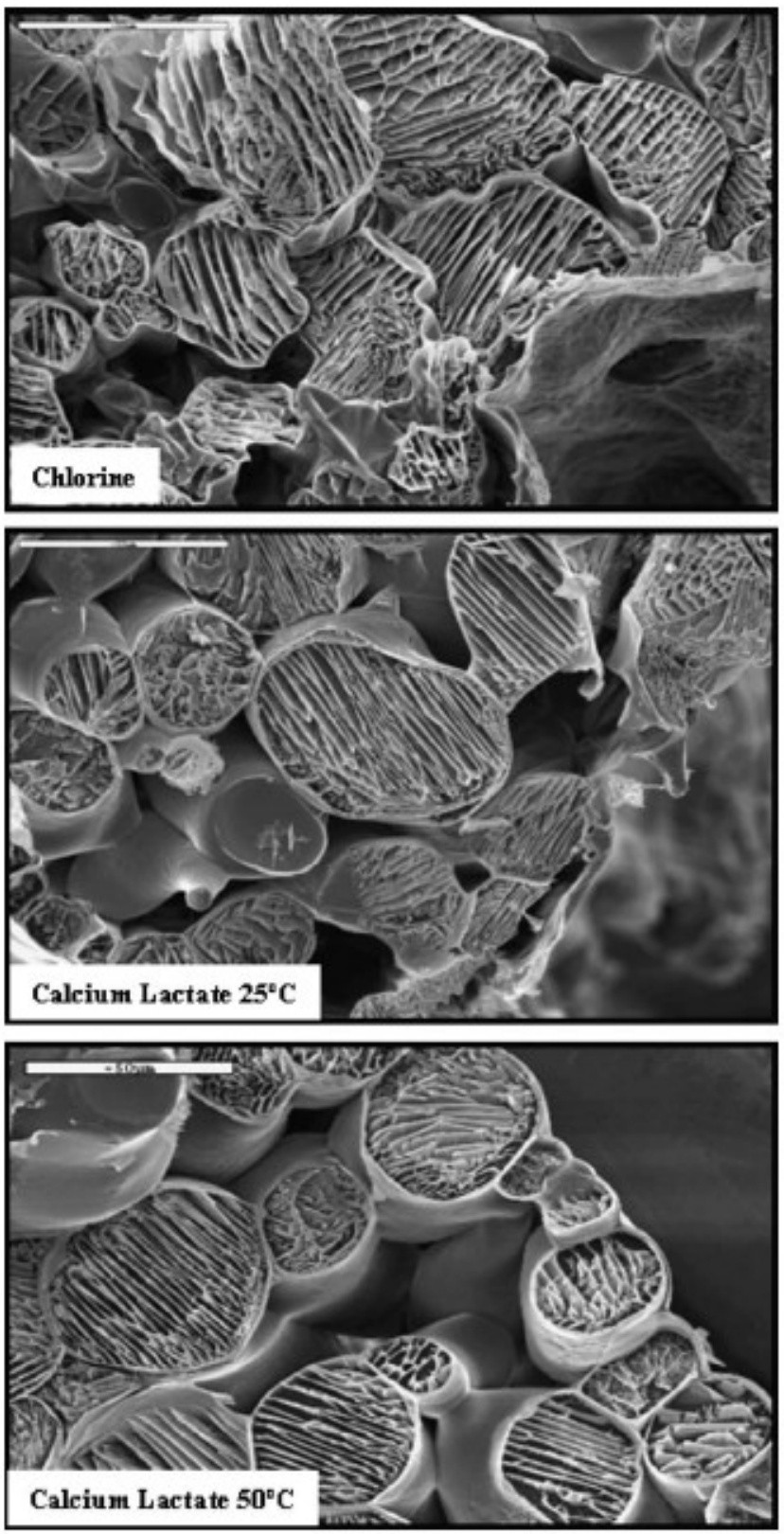

Fig. 1. Cryo-scanning electron micrographs of fresh-cut lettuce washed with $120 \mathrm{mg} / \mathrm{L}$ chlorine, $15 \mathrm{~g} / \mathrm{L}$ calcium lactate at room temperature (18$20^{\circ} \mathrm{C}$ ) and $50^{\circ} \mathrm{C}$ (heat-shock) after 1 day of storage at $4{ }^{\circ} \mathrm{C}$.

resistance it is the pressure exerted on the cell wall that accounts for the turgor pressure-induced elasticity of cells and tissues. This would suggest that the loss of turgor observed for chlorine samples (Fig. 1) might produce a loss of crispness. This suggestion was confirmed using texturometer measurements (see data below) which found lower crispness coefficient values in samples treated with chlorine.

An advanced state of plasmolysis and/or shrinkage of the cells were observed in samples treated with chlorine or calcium lactate at room temperature after 10 days storage (Fig. 2). This degradation is involved in the ripening process and is associated with enzymatic pectin hydrolysis during post-harvest storage. Samples washed with calcium 

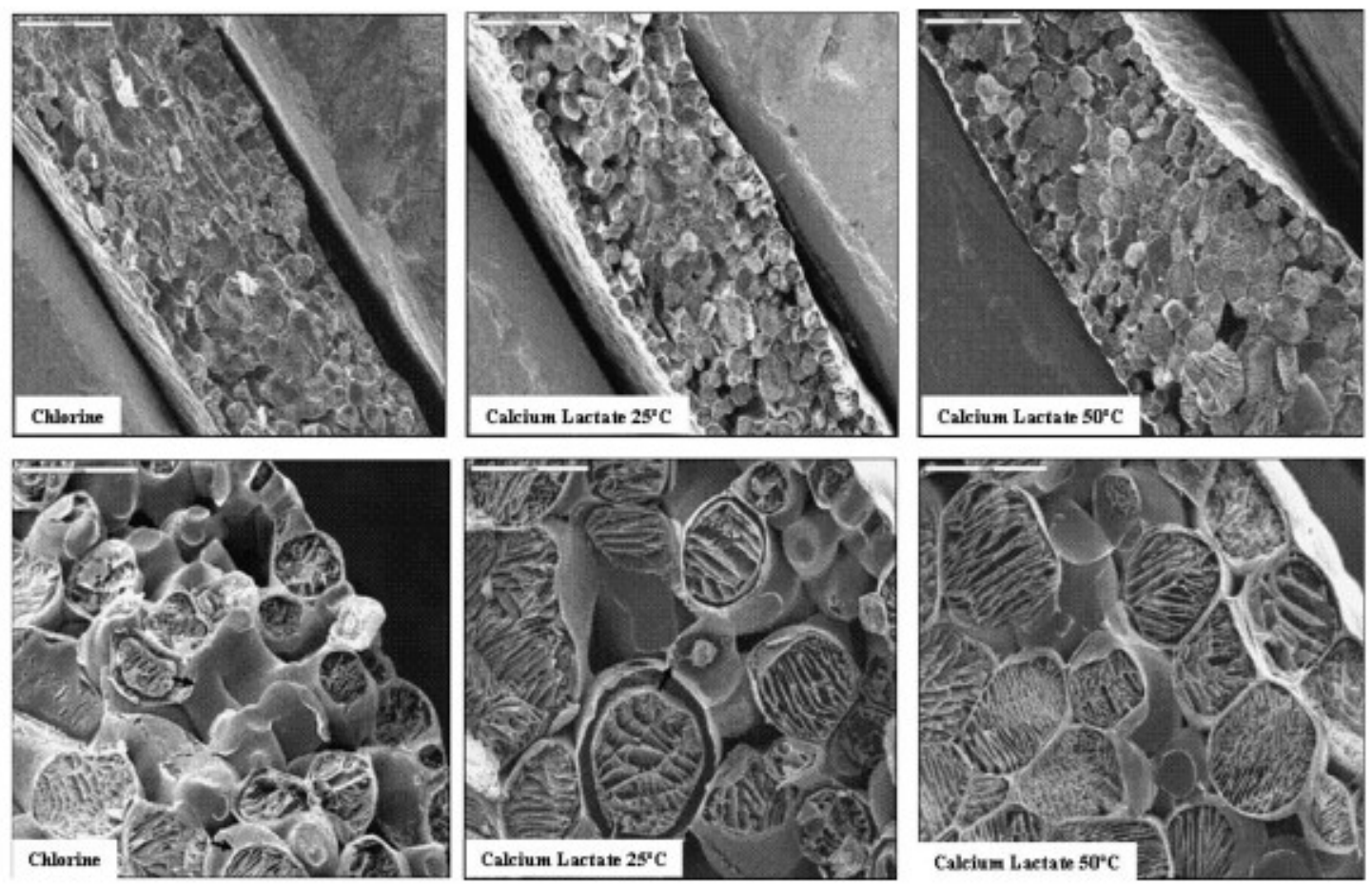

Fig. 2. Cryo-scanning electron micrographs of fresh-cut lettuce washed with $120 \mathrm{mg} / \mathrm{L}$ chlorine, $15 \mathrm{~g} / \mathrm{L}$ calcium lactate at room temperature $\left(18-20^{\circ} \mathrm{C}\right)$ and $50{ }^{\circ} \mathrm{C}$ (heat-shock) after 10 days of storage at $4{ }^{\circ} \mathrm{C}$.

lactate at $50{ }^{\circ} \mathrm{C}$ maintained a better structure at the end of the storage compared with chlorine and calcium lactate (room temperature) treated samples.

Thus, calcium lactate helped to maintain cell turgor better than chlorine after the first day of storage while for longer storage times the use of high temperatures showed better preservation of turgor. The effect of temperature on the diffusion of calcium may be an important factor, increasing the permeability and solubility of the calcium throughout the tissues (Bartolome \& Hoff, 1972; Garcia et al., 1996). Also, the treatment at $50^{\circ} \mathrm{C}$ might have expanded the air within the lettuce tissues, and the subsequent cooling and contraction of this air would have absorbed the surrounding water into the lettuce, therefore keeping better the moisture and turgor of the cells.

\subsection{Instron analysis}

The instrumental measurement of lettuce texture is difficult to carry out, due mainly to the high variability of the product. Lettuce contains two different types of tissue (vascular and photosynthetic) which are not always easy to differentiate and have an irregular distribution. The relative position of vascular packages (parallel, oblique and perpendicular orientations) with respect to the texturometer cell blades directly affects the measurement (Toole et al., 2000).

The texturometer analyses showed that lettuce pieces with the vascular tissue oriented perpendicular or oblique with respect to the Kramer blades needed significant $(p<0.05)$ higher load values to be broken than pieces with parallel orientation (data not shown). The vascular veins which transport nutrients and water are reinforced with a matrix (parenchyma). When this parenchyma had a perpendicular or oblique orientation the force to shear the veins was higher than when in the parallel orientation. Thus, in the parallel orientation the force was employed in the separation of the vascular fibres and breaking of the tissue while in the other two positions the vascular parenchyma needed to be broken (Toole et al., 2000).

A significant $(p<0.05)$ correlation between weight and maximum load needed to break the sample was observed, as expected. The ratio maximum load/weight significantly $(p<0.05)$ changed during storage. This behaviour may be related with a loss of turgor producing a decrease in the maximum load needed for the test. This decrease in maximum load was observed in all the samples during storage (data not shown). However, significant differences between treatments were not found.

Different behaviours of the load-displacement profile using the Kramer cell were observed depending on the crispness of the samples. In Fig. 3 the profiles for a crispy sample (Fig. 3(a)) and a soft (limp) sample (Fig. 3(b)) are shown. Samples with higher crispness showed an increase in the maximum load, reaching the maximum at the rupture point, followed by a rapid decrease to values close to zero after breaking (Fig. 3(a)). However, in the limp samples the maximum load increased to the rupture point (which was a lower value than for to crispy samples), but due to the elasticity of these samples the drop in load immediately after this point was less noticeable (Fig. 3(b)). The use of a coefficient based on the maximum 

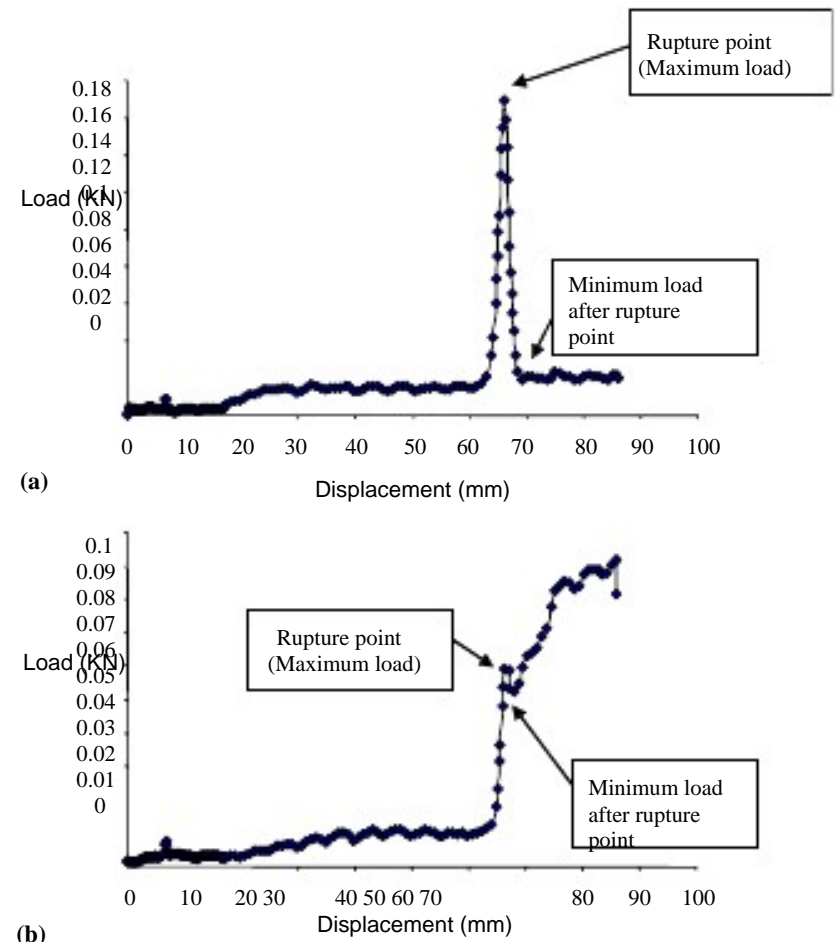

Fig. 3. Displacement $(\mathrm{mm})$ versus load $(\mathrm{KN})$ of a crispy fresh-cut lettuce sample (a) and soft-limp fresh-cut lettuce sample (b) analysed with a Kramer shear cell.

load and the minimum load immediately after the breaking point, which was called crispiness coefficient (CC), was a useful tool to distinguish between treatments, which could not be distinguished by means of the ratio maximum load/ weight.

Significantly higher values $(p<0.05)$ of $C C$ were observed in samples treated with calcium lactate than chlorine and the differences between vascular tissue orientations observed in the maximum load/weight ratio disappeared when the CC was used (Fig. 4). Samples treated with

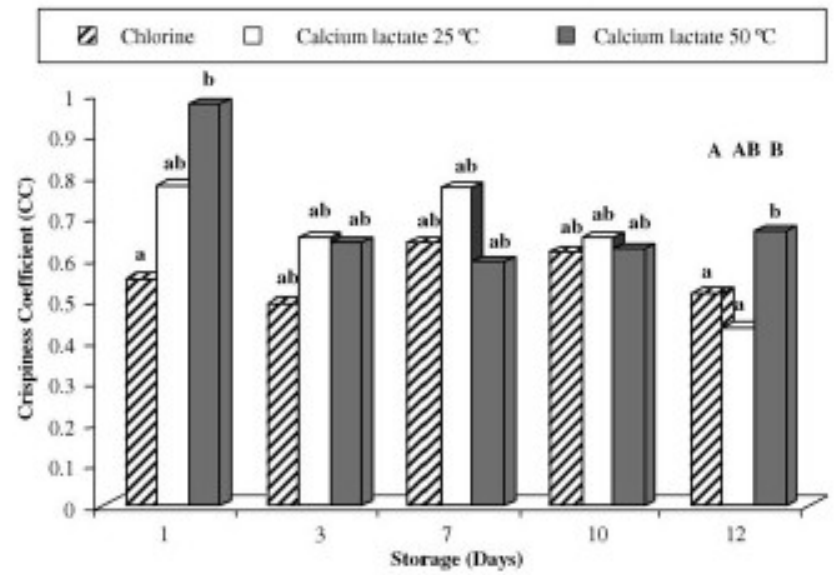

Fig. 4. Effect of washing treatment $(120 \mathrm{mg} / \mathrm{L}$ chlorine, calcium lactate at room temperature and calcium lactate at $50^{\circ} \mathrm{C}$ ) in Kramer texture analysis (crispness coefficient (CC)) in fresh-cut lettuce stored 12 days at $4{ }^{\circ} \mathrm{C}$. calcium lactate at $50^{\circ} \mathrm{C}$ showed higher $\mathrm{CC}$ values after the initial treatment (day 1) than samples washed with calcium lactate and chlorine at room temperature. In addition, the former showed higher maximum load at breaking point than the latter. These results were in agreement with the microstructural analysis (Figs. 1 and 2) where the lettuce treated with chlorine showed a greater loss of turgor in the cells than samples treated with calcium. This loss in turgor might have produced a loss of crispness and thus lower load would be needed to break the tissue.

At the end of storage (day 12) the samples treated with calcium and heat-shock showed higher CC values, which was interpreted as a higher crispness (Fig. 4).

\subsection{Dry matter}

A significant $(p<0.05)$ decrease in dry matter was observed during storage for all samples (Table 1). The samples treated with calcium lactate had a significant $(p>0.05)$ lower loss of water than the samples treated with chlorine. This might correspond to the formation of calcium pectate in the cell wall which is associated with a higher water retention capacity (Jackman \& Stanley, 1995). Samples treated with heat-shock and calcium showed a lower loss of dry matter, which may be correlated with better turgor maintenance (Figs. 1 and 2).

\subsection{Sensory analysis}

Sensorial analysis of the texture attributes (crispiness) was carried out in samples during storage (Fig. 5). Significant changes in the texture during storage were observed $(p<0.05)$. The samples treated with calcium lactate at $50{ }^{\circ} \mathrm{C}$ scored higher values for texture (crispness) than samples treated with chlorine over the storage period.

These results were supported by the findings in the SEM micrographs, where samples treated with calcium lactate at $50{ }^{\circ} \mathrm{C}$ showed higher cell turgor (less shrinkage) than samples treated at room temperature with chlorine and calcium lactate. The $\mathrm{CC}$ values were also higher in samples treated with calcium lactate at $50{ }^{\circ} \mathrm{C}$.

Table 1

Dry matter values for fresh-cut lettuce washed with $120 \mathrm{mg} / \mathrm{L}$ chlorine, calcium lactate at room temperature and calcium lactate at $50{ }^{\circ} \mathrm{C}$ and stored 12 days at $4{ }^{\circ} \mathrm{C}$

\begin{tabular}{llll}
\hline \multirow{2}{*}{ Storage } & \multicolumn{3}{l}{ Dry matter $(\%)$} \\
\cline { 2 - 4 } & Chlorine & Calcium lactate $25^{\circ} \mathrm{C}$ & Calcium lactate $50^{\circ} \mathrm{C}$ \\
\hline 1 & $3.36 \pm 0.01 \mathrm{~b}$ & $3.60 \pm 0.1 \mathrm{bc}$ & $4.18 \pm 0.37 \mathrm{c}$ \\
3 & $3.05 \pm 0.10 \mathrm{ab}$ & $3.27 \pm 0.08 \mathrm{~b}$ & $2.94 \pm 0.11 \mathrm{ab}$ \\
7 & $2.86 \pm 0.10 \mathrm{a}$ & $2.82 \pm 0.2 \mathrm{a}$ & $3.30 \pm 0.01 \mathrm{~b}$ \\
10 & $3.18 \pm 0.10 \mathrm{a}$ & $2.97 \pm 0.14 \mathrm{a}$ & $3.32 \pm 0.21 \mathrm{~b}$ \\
12 & $3.23 \pm 0.10 \mathrm{ab}$ & $3.02 \pm 0.10 \mathrm{ab}$ & $3.38 \pm 0.20 \mathrm{~b}$ \\
\hline
\end{tabular}

Values designated by the same letter are not significantly different $(p>0.05)$. Lower case letter are used for comparisons during storage. 


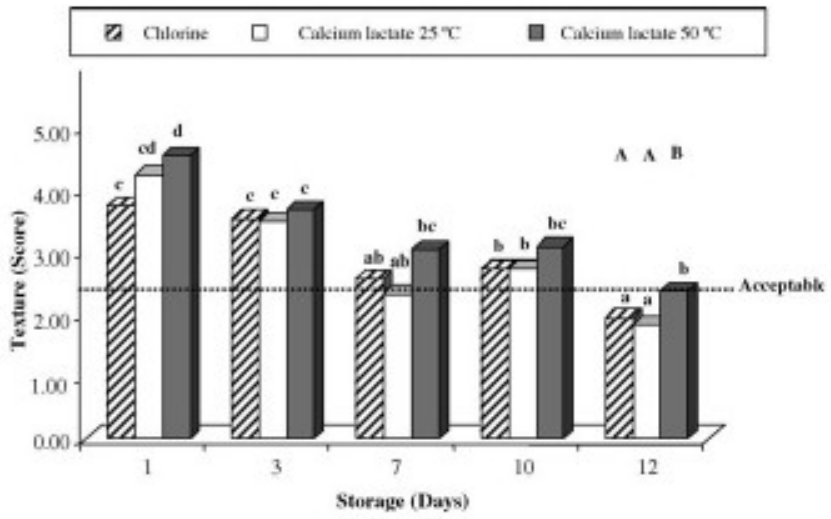

Fig. 5. Sensory analysis (texture) for fresh-cut lettuce washed with $120 \mathrm{mg} / \mathrm{L}$ chlorine, calcium lactate at room temperature and calcium lactate at $50{ }^{\circ} \mathrm{C}$ and stored 12 days at $4{ }^{\circ} \mathrm{C}$. A hedonic scale $(0-5)$ was used to evaluate texture. Scores of 2.5 was considered a limit as acceptable for the consumerÕs acceptance.

\subsection{Pectin methyl esterase}

Overall, PME activity increased significantly during storage for all the treatments (Fig. 6) although its activity fluctuated within the storage period. This irregular behaviour may be due to a wounding response and/or to changes in the solubility of the enzyme during storage (Masih, Roginski, Premier, Tomkins, \& Ajlounia, 2002). Such behaviour has been observed for certain browning-related enzymes (Cantos, Espin, \& Tomas-Barberan, 2001).

Neither calcium lactate nor chlorine showed a significant effect on PME activity (Fig. 6). Treatment with high temperature $\left(50^{\circ} \mathrm{C}\right)$ was the only parameter that significantly affected the PME activity. PME activity was higher in samples treated at $50{ }^{\circ} \mathrm{C}$ than at $25^{\circ} \mathrm{C}$ (Fig. 6). These results are consistent with other studies that show treatments with calcium solutions at temperatures over $50{ }^{\circ} \mathrm{C}$ increase

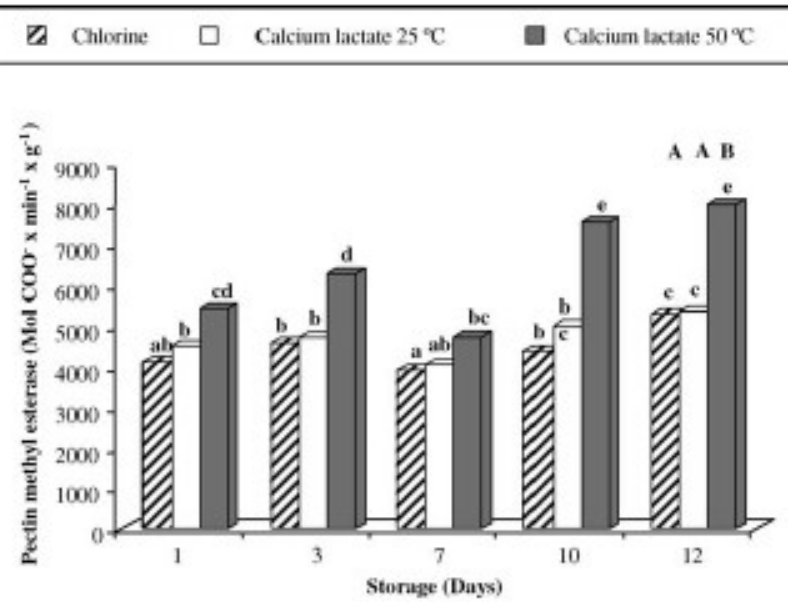

Fig. 6. Pectin methyl esterase activity (PME) fresh-cut lettuce washed with $120 \mathrm{mg} / \mathrm{L}$ chlorine, calcium lactate at room temperature and calcium lactate at $50{ }^{\circ} \mathrm{C}$ and stored 12 days at $4{ }^{\circ} \mathrm{C}$.
PME activity (Bartolome \& Hoff, 1972; Garcia et al., 1996).

The beneficial effects on texture of heat treatments and calcium solution washes have usually been explained in terms of the activation of pectin methyl esterase (PME) (Bartolome \& Hoff, 1972). PME is responsible for cleaving the methoxyl groups from methylated pectic substances, generating free pectic acids (Belitz \& Grosh, 1986), which contain newly available carboxyl groups. Endogenous and added calcium can make plant tissue firmer by binding to the pectin carboxyl groups that are generated through the action of PME (Stanley, Bourne, Stone, \& Wismer, 1995).

\section{Conclusion}

The crispness coefficient (CC) showed higher values in samples treated with $15 \mathrm{~g} / \mathrm{L}$ calcium lactate, compared with $120 \mathrm{ppm}$ chlorine treatment, in agreement with the sensory result and Crio-SEM micrographs. The use of $50{ }^{\circ} \mathrm{C}$ temperature revealed fundamental in maintaining the crispness of the vegetable. Calcium lactate avoided the loss of turgor during the first days of storage; however the combination with $50{ }^{\circ} \mathrm{C}$ temperature (heat-shock) extended this benefit to the end of the storage ( 12 days). Possible mechanism suggested to be involved in this effect are the activation of texture-related enzymes, as the PME, an effect of washing solution absorption into the lettuce, which might increase the amount of calcium retained by vegetable or the increasing in the diffusive processes by temperature, including the calcium.

The $\mathrm{C} C$ revealed useful for measuring the crispy property of fresh-cut lettuce. Combined heat-shock $\left(50^{\circ} \mathrm{C}\right)$ and calcium lactate treatment resulted better for maintaining the texture of the fresh-cut lettuce than the treatments with calcium lactate and chlorine at room temperature.

\section{Acknowledgements}

This research was supported by a Technological Sector Research Grant (2002-2006). The authors would like to thank the electron microscopy service at University 'Politecnica of Valencia for the technical advices.

\section{References}

Alsadon, A. A. (1993). Sensory quality attributes of butterhead lettuce cultivars grown in arid conditions. Hortscience, 28(2), 159-160. 'Artes, F., \& Martinez, J. A. (1996). Influence of packaging treatments on the keeping quality of "Salinas" lettuce. Lebensmittel Wissenschaft und Technologie, 29(7), 664-668.

Bartolome, L. G., \& Hoff, J. E. (1972). Firming of potatoes: biochemical effect of preheating. Journal of Agricultural and Food Chemistry, 20, 266-270.

Baur, S., Klaiber, R., Wei, H., Hammes, W. P., \& Carle, R. (2005). Effect of temperature and chlorination of pre-washing water on shelf-life and physiological properties of ready to use iceberg lettuce. Innovative Food Science and Emerging Technologies, 6, 171-182. 
Belitz, H. D., \& Grosh, W. (1986). Food chemistry (2nd ed.). New-York: Springer-Verlag (p. 774).

Bomben, J. L., \& King, C. J. (1982). Heat and mass transport in the freezing of apple tissue. Journal of Food Technology, 17, 615-632.

Bourne, M. C. (1976). Texture of fruits and vegetables. In J. M. DeMan, P. W. Rasper, V. F. Rasper, \& D. W. Stanley (Eds.), Rheology and texture in food quality (pp. 275-307). New York: Van Nostrand Reinhold/AVI.

Bourne, M. (2002). Food texture and viscosity (2nd ed.). Food science and technology, international series. San Diego, CA: Academic Press.

Brecht, J. K. (1995). Physiology of lightly processed fruits and vegetables. Horticultural Science, 301, 8-22.

Camire, E. M., Ismail, S., Work, T. M., Bushway, A. A., \& Halteman, W. A. (1994). Improvements in canned lowbush blueberry quality. Journal of Food Science, 59, 394-398.

Cantos, E., Espin, J. C., \& Tomas-Barberan, F. A. (2001). Effect of wounding on phenolic enzymes in six minimally processed lettuce cultivars upon storage. Journal of Agricultural and Food Chemistry, 49(1), 22-30.

Fillion, L., Kilcast, D. (2000). Concept and measurement of freshness of fruits and vegetables. Leatherhead Food RA Research Reports No. 770 .

Fillion, L., \& Kilcast, D. (2002). Consumer perception of crispiness and crunchiness in fruits and vegetables. Food Quality and Preference, 13, 23-29.

Floros, J. D., Ekanayake, A., Abide, G. P., \& Nelson, P. E. (1992). Optimization of postharvest dips in calcium chloride on strawberry. Journal of Agricultural and Food Chemistry, 4, 30-33.

Garcia, J. M., Herrera, S., \& Morilla, A. (1996). Effects of postharvest dips in calcium chloride on strawberry. Journal of Agricultural and Food Chemistry, 44, 30-33.

Giner, J., Gimeno, V., Espachs, A., Elez, P., Barbosa-Canovas, G. V., \& Martin, O. (2000). Inhibition of tomato (Licopersicon esculentum Mill.) pectin merhylesterase pulsed electric fields. Innovative Food Science and Emerging Technologies, 1, 57-67.

Grant, G. T., Morris, E. R., Rees, D. A., Smith, P. J. C., \& Thom, D. (1973). Biological interactions between polysaccharides and divalent cations: the egg-box model. FEBS Letters, 32, 195-198.

Grass, M. L., Vidal, D., Betoret, N., Chiralt, A., \& Fito, P. (2003). Calcium fortification of vegetables by vacuum impregnation interactions with cellular matrix. Journal of Food Engineering, 56, 279284.

Han, J., Gomes-Feitosa, C. L., Castell-Perez, E, Moreira, R. G., \& Silva, P. F. (2004). Quality of packaged romaine lettuce hearts exposed to low-dose electron beam irradiation. Lebensmittel Wissenschaft und Technologie, 37, 705-715.

Harker, F. R., Stec, M. G. H., Hallett, I. C., \& Bennett, C. L. (1997). Texture of parenchymatous plant tissue: a comparison between tensile and other instrumental and sensory measurements of tissue strength and juiciness. Postharvest Biology and Technology, 11, 63-72.

Heimdal, H., Kuhn, B. F., Poll, L., \& Larsen, L. M. (1995). Biochemical" changes and sensory quality of shredded and MA-Packaged Iceberg lettuce. Journal of Food Science, 60(6), 1265-1276.

Hisaminato, H., Murata, M., \& Homma, S. (2001). Relationship between enzymatic browning of cut lettuce and phenylalanine ammonialyase activity, and prevention of browning by inhibitors of polyphenol biosynthesis. Bioscience, Biotechnology and Biochemistry, 65, 1016-1021.

Jackman, R. L., \& Stanley, D. W. (1995). Perspectives in the textural evaluation of plant foods. Trends in Food Science and Technology, 6(6), 187-194.

Kimball, D. A. (1991). Citrus processing-quality control and technology New York: Van Nostrand Reinhold.

King, A. D., Jr., \& Bolin, H. R. (1989). Physiological and microbiological storage stability of minimally processed fruits and vegetables. Food Technology, 43, 132-135.

Lester, G. E., \& Grusak, M. A. (1999). Postharvest application of calcium and magnesium to honeydew and netted muskmelons: effects on tissue ion concentrations, quality, and senescence. Journal of the American Society for Horticultural Science, 124, 545-552.

Loaiza-Velarde, J. G., Tomas-Barberan, F. A., \& Salveit, M. E. (1997)

Effect of intensity and duration of heat shock treatment on woundinduced phenolic metabolism in Iceberg lettuce. Journal of the American Society for Horticultural Science, 122, 873-877.

Luna-Guzman, I., \& Barrett, D. M. (2000). Comparison of calcium chloride and calcium lactate effectiveness in maintaining shelf stability and quality of fresh-cut cantaloupe. Postharvest Biology and Technology, 19, 61-72.

Luna-Guzman, I., Cantwell, M., \& Barrett, D. M. (1999). Fresh-cut cantaloupe: effects of $\mathrm{CaCl}_{2}$ dips and heat treatments on firmness and metabolic activity. Postharvest Biology and Technology, 17, 201-213.

Main, G. L., Morris, J. R., \& Wehunt, E. J. (1986). Effect of preprocessing treatment on the firmness and quality characteristics of whole and sliced strawberries after freezing and thermal processing Journal of Food Science, 51, 391-394.

Martin-Diana, A. B., Rico, D., Barry-Ryan, C., Frias, J., Mulcahy, J., \& Henehan, G. T. M. (2005-a). Comparison of calcium lactate with chlorine as a washing treatment for fresh-cut lettuce and carrots: quality and nutritional parameters. Journal of the Science of Food and Agriculture, 51, 391-394.

Martin-Diana, A. B., Rico, D., Barry-Ryan, C., Frias, J. M., Mulcahy, J., \& Henehan, G. T. M. (2005-b). Effect of calcium lactate concentration and temperature washing treatments on quality retention of salad-cut Iceberg lettuce. Food Research International, 38, 729-740.

Martin-Diana, A. B., Rico, D., Frias, J. M., Barry-Ryan, C., Mulcahy, J., \& Henehan, G. T. M. (2005-c). Effect of heat-shock on browningrelated enzymes in minimally processed Iceberg lettuce and crude extracts. Bioscience Biotechnology and Biochemistry, 69(9), 1677-1685.

Masih, L., Roginski, H., Premier, R., Tomkins, B., \& Ajlounia, S. (2002). Soluble protein content in minimally processed vegetables during storage. Food Research International, 35, 697-702.

Mazza, G. (1998). Functional foods: Biochemical and processing aspects. Lancaster: Technomic Publishing Company.

Morris, J. R., Sistrunk, W. A., Sims, C. A., Main, G. L., \& Wehunt, E. J. (1985). Effects of cultivar, postharvest storage, pre-processing dip treatments and style of pack on the processing quality of strawberries. Journal of the American Society for Horticultural Science, 110, 172-177.

Ohlsson, T. (1994). Minimal processing-preservation methods of the future-an overview. Trends in Food Science and Technology, 5, 341-344

Rojas, A. M., Gerschenson, L. N., \& Marangoni, A. G. (2001). Contributions of cellular components to the rheological behaviour of kiwifruit. Food Research International, 34, 189-195.

Roy, S., Watada, A. E., Conway, W. S., Erbe, E. F., \& Wergin, W. P. (1994). Low-temperature scanning electron microscopy of frozen hydrated apple tissues and surface organisms. Hortscience, 29, 305-309.

Ruowei, L., Serdula, M., Bland, S., Mokdad Bowman, B., \& Nelson, D. (2000). Trends in fruit and vegetable consumption among adults in 16 states: Behavioral Risk Factor Surveillance System 1990-1996. American Journal of Public Health, 90, 777-781.

Stanley, D. W., Bourne, M. C., Stone, A. P., \& Wismer, W. V. (1995). Low temperature blanching effects on chemistry firmness and structure of canned green beans and carrots. Journal of Food Science, 60, 327-333.

Subar, A. F., Heimendinger, J., Patterson, B. H., Krebs-Smith, S. M., Pivonka, E., \& Kessler, R. (1995). Fruit and vegetable intake in the United States: the baseline survey for the five a day for better health program. American Journal of Health Promotion, 9, 352-360.

Suutarinen, J., Anakainen, L., \& Autio, K. (1999). Comparison of light microscopy and spatially resolved Fourier transform infrared (FT-IR) microscopy in the examination of cell wall components of strawberries. Lebensmittel Wissenschaft und Technologie, 31, 595-601.

Szczesniak, A. S. (1998). The meaning of textural characteristics of crispiness. Journal of Texture Studies, 19, 51-59. 
Toole, G. A., Parker, M. L., Smith, A. C., \& Waldron, K. W. (2000). Mechanical properties of lettuce. Journal of Material Science, 35, 3553-3559.

Vickers, A. M. (1988). Instrumental measures of crispiness and their correlation with sensory assessment. Journal of Texture Studies, 19, $1-14$
Vu, T. S., Smout, C., Sila, D. N., Ly Nguyen, B., Van Loey, A. M. L., \& Hendrickx, M. E. G. (2004). Effect of preheating on the thermal degradation kinetics of carrot texture. Innovative Food Science and Emerging Technologies, 5, 37-44.

Watada, A. E., \& Qui, L. (1999). Quality of fresh-cut produce. Postharvest Biology and Technology, 15, 201-205. 